\title{
Editorial: Just Remembering or Remembering Rightly Cathy Ross
}

This issue of ANVIL focuses on remembrance and what it means to remember rightly, along with related themes of justice and forgiveness. The current issue has been prompted by this year of 2014 when we remember the anniversary of the beginning of the First World War. We also remember other anniversaries - twenty years since the genocide in Rwanda, twenty years since the first democratic elections in the Republic of South Africa, thirty years since the Brighton bombing committed by the IRA.

We all know that remembering history is a tricky thing and that what you see or hear or remember depends on where you stand. There is the well-known African proverb, 'Until lions have their historians, tales of the hunt shall always glorify the hunter.' Recent approaches to history have focused on trying to understand history from the underside so that we receive a more fully orbed perspective. However, these articles are not so much about trying to understand or remember history as it was - if we can ever claim to do that rather they reflect on how what we remember affects us now. Our memories can shape and form us, they can even imprison us and prevent us from living life to its fullness as God intends for us. Painful memories can be debilitating not only for the person concerned but also for those around them. It can take courage to confront painful memories, to face the past and to be able to live in the present without being crippled or paralysed by our past. This also provokes questions around forgiveness - a concept with which we as Christians are familiar, although as Lesly Bilinda points out in her article, the word 'forgive' is mentioned very few times in the New Testament.

After reading these articles, it seems that forgiveness may be a more difficult concept than I had first realised and of course, it works on various levels. It is a fairly trivial matter to 'forgive' to someone for forgetting to turn up for a meal you prepared, or for losing one of your beloved books; it is far more difficult and complex to forgive someone for abusing you or your child, or for murder. And what about justice? The murderer or abuser may receive due punishment and according to the law, justice has been carried out, but how does that help the victim or the victim's family?

The interview with Jo Berry, daughter of murdered politician Sir Anthony Berry in the 1984 Brighton bombing, considers exactly this. She quotes Michael Lapsley's concept of 'bicycle forgiveness.' In other words, I may forgive you for stealing my bicycle but you still have my bicycle (or my father is still dead or my daughter's abuse is still a reality). What is justice in those scenarios? Jo also explores what forgiveness means for her, after years of a growing friendship with Pat Magee, one of the bombers who murdered her father. Jo talks about the empathy she began to experience as she got to know Pat and to hear his story and how this has freed her from bitterness and hatred towards him. She can now see and experience 
their shared humanity and this has also freed her from a kind of unhelpfully virtuous attitude where the one who forgives can remain in a kind of superior and self-righteous place.

Revd Lesley Bilinda also reflects on forgiveness from her experience of losing her Rwandan husband in the genocide twenty years ago. She too has found that forgiveness is more complex than we might think. She claims, that 'forgiveness, if it is to happen at all, may not be considered for some time after the event.' Using Jesus' example, she reflects on how important our own response is to any injustice done to us. She concludes by finding help and strength in the eucharist where she explains that we are dis-membered and remembered and so are made whole again, through the power and inspiration of the Holy Spirit.

Revd Lesley Carroll remembers her recent past from the context of Northern Ireland. She has served on a government appointed commission to consider how to deal with Northern Ireland's troubled past and has worked with victims and survivors from all political backgrounds as a minister and most recently as an associate member of the Northern Ireland Forum for Victims and Survivors. She asserts that remembering is a duty to both the living and the dead and that to forget is not an option anyway as every week new issues emerge, new inquiries are called for, new evidence emerges. She claims that it is more helpful to think of remembering as a narrative that shapes our lives rather than a one-off static event. She considers what it means to live in a context where remembering is contested as it is in Northern Ireland. She relates the story of 'The Day of Private Reflection' to elucidate how this has become a contested space and she links this to the story of the Passover and finally what it means to remember the Crucifixion. She affirms that remembering must be inclusive of all the differing ways of remembering if peacemaking is to be constructive and betrayal not to be experienced. She offers a cautionary warning: 'betrayal is likely to store up outrage that will one day manifest itself.'

The final article by Rt Revd Christopher Hill offers a fascinating summary of faith and patriotism before, during and after the First World War. This is a more historical piece presenting us with broad brush strokes on a larger canvas than the previous articles, all of which emerge out of personal experience and reflection. Bishop Christopher offers compelling insights into pre-war English and German theological trends and how the context of the war challenged and changed theological insights on both sides. This clearly points to issues of contextualization, how much of our theology is affected (for good or ill) by our contexts and just how difficult it is to see clearly, when we are in the midst of the situation, exactly how our theology can enhance the context or when it needs to challenge the context. It is always easier to spot compromise and collusion in another's culture than in one's own, which is why we need the good relationships with the world church to help us see the logs in our own eyes. Hill relates an intriguing story of how patriotism and nationalism seemed to trump relationships and of how good people can be found on both sides of a divide. It is salutary reading as we consider some of the issues of our own day.

The issue concludes with an excellent clutch of book reviews for your reading pleasure! 